\title{
Blood pressure and PAOI score in patients with pulmonary embolism
}

\section{(DAlen Džubur ${ }^{*}$, - $D$ Edin Begić2 - Alden Begić', CDirza Babićs (1)Azra Durak- Nalbantić1}

'Clinical Center University of Sarajevo, Sarajevo, Bosnia and Herzegovina

${ }^{2}$ General Hospital "Prim.dr. Abdulah Nakaš", Sarajevo, Bosnia and Herzegovina

${ }^{3}$ Cantonal Hospital Bihać, Bihać, Bosnia and Herzegovina
RECEIVED:

November 13, 2020

ACCEPTED:

December 18, 2020

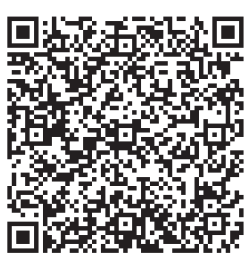

$\square$ Cardiologia Croatica 2021;16(1-2):78.
KEYWORDS: pulmonary embolism, blood pressure, acute cardiology.

CITATION: Cardiol Croat. 2021;16(1-2):78-9. | https://doi.org/10.15836/ccar2021.78

*ADDRESS FOR CORRESPONDENCE: Alen Džubur, Klinički Centar Univerziteta u Sarajevu, Bolnička 25, 71000 Sarajevo, Bosnia and Herzegovina. / Phone: +38761483259 / E-mail: alendzubur@gmail.com

ORCID: Alen Džubur, https://orcid.org/0000-0003-1198-540X • Edin Begić, https://orcid.org/0000-0001-6842-262X

Alden Begić, https://orcid.org/0000-0002-5374-0892 • Mirza Babić, https://orcid.org/0000-0001-7240-7940

Azra Durak-Nalbantić, https://orcid.org/0000-0002-5175-8941

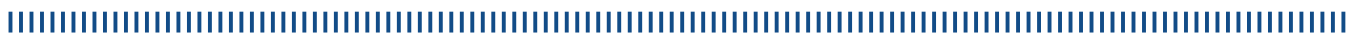

Aim: To connect the values of systolic and diastolic blood pressure at the admission of a patient with a diagnosis of pulmonary embolism (PE) with the values of the degree of pulmonary artery obstruction index (PAOI score).

Patients and Methods: Patients were hospitalized under a diagnosis of pulmonary embolism, which was confirmed on the basis of the following criteria: clinical picture, changes in the electrocardiogram (ECG), serum D-dimer values and computed tomography (CT) angiography with contrast. The PAOI score was determined according to CT findings. On admission, systolic, diastolic and pulse pressure were measured.

Results: The mean systolic blood pressure was $124.4 \pm 27.75 \mathrm{mmHg}$, and there was a statistically significant correlation between the PAOI score and the systolic blood pressure $(p=0.004)$, with a significant negative correlation between the values of the PAOI score and the values of systolic blood pressure $(\mathrm{r}=-0.328, \mathrm{p}=0.018)$ (Figure 1). The mean value of diastolic blood pressure was $78.5 \pm 14.06 \mathrm{mmHg}$. A statistically non-nsignificant negative correlation between PAOI score and diastolic blood pressure value was verified $(r=-0.149, p=0.293)$. The mean value of pulse pressure was $45.21 \pm 19.09 \mathrm{mmHg}$, with statistical significance between PAOI score and the value of pulse pressure $(p=0.001)$. A statistically significant negative correlation between PAOI score and pulse pressure value was verified $(r=-0.366$, $\mathrm{p}=0.008)$

Conclusion: Lower systolic blood pressure values are associated with more extensive pulmonary embolism. ${ }^{1}$ 


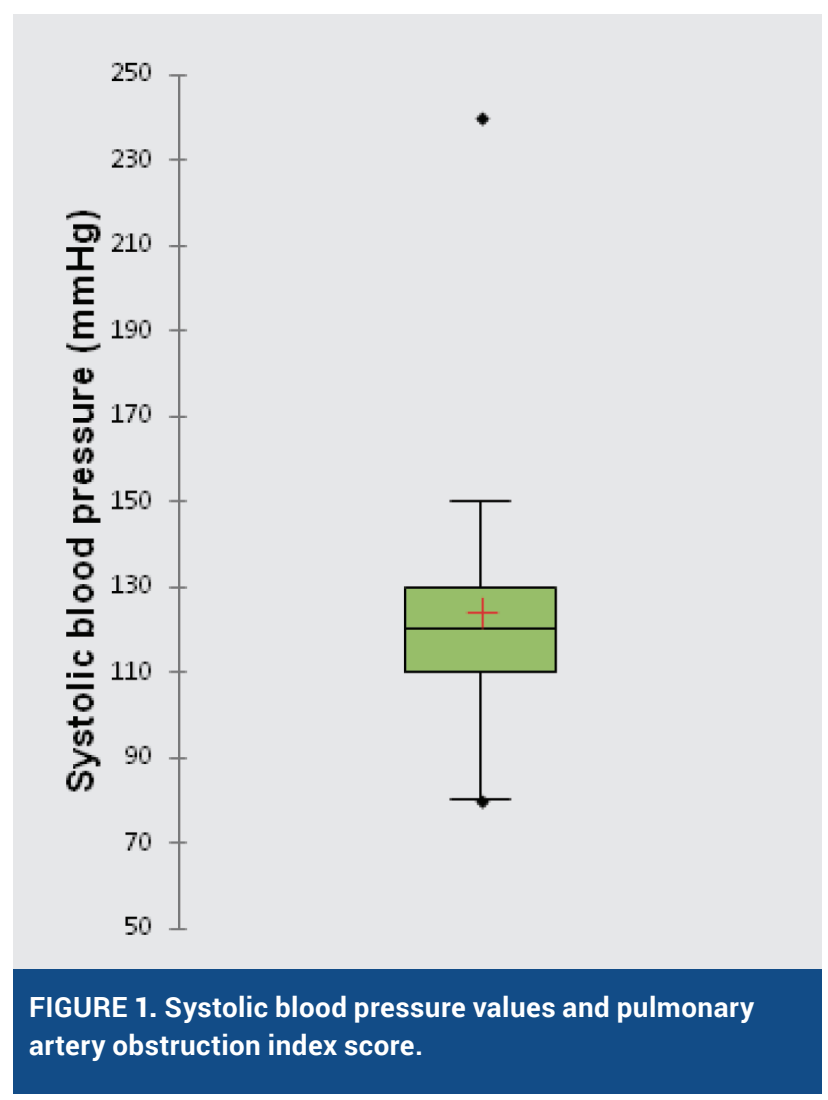

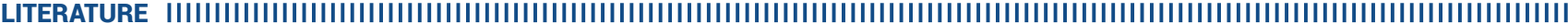

1. Faghihi Langroudi T, Sheikh M, Naderian M, Sanei Taheri M, Ashraf-Ganjouei A, Khaheshi I. The Association between the Pulmonary Arterial Obstruction Index and Atrial Size in Patients with Acute Pulmonary Embolism. Radiol Res Pract. 2019 June 2;2019:6025931. https://doi.org/10.1155/2019/6025931 